State of Alagka

lepartment of Natural Resources

P. O. Box 1391

IIVISION OF MINES AND MINERRALS

Juneau, Alesses

MTVES BULTERTN

Vol. VIII

April, 1960

No. 4

\title{
MIIING ACTIVITIES
}

The U.S. Smelting, Reflaing and Mining Co. will operate four dredges in the Fairbenks District, one at Chicken in the Fortymile, one at Hog River in the lower Koyulouk country, and two or three near Nome this year. About 250 men w1ll be hired out of Fairbanks and posstbly 125 at Nome.

\section{OII NEWS}

The best well yet wes brought in during the month. It is the Standard-Richfield Soldotna Creek Un1t No. $41-4$ on the Kena1 Peninsula. Tests have been conpleted and It 18 estimated that the maximum efficient rate of production from this well wiIl be between 700 and 800 barrels per day. The producing interval 18 epparently from 10,230' to 10,585'.

Kenal comounity residents propose to incorporate and to include within the c1ty limits the three Union-Ohio gas wells located 4 to 6 miles south of the town and also the off'shore area for which Union bid and pald over $\$ 1,000,000$ at the last lease sale. The matter is before the State Superior Court.

The State Division of Lands will hold a hearing on April 22 at 10:00 AM regarding adoption of an amendment to Section 515.72, Title 11, AAC, pertaining to oll and ges leasing. The amendment would extend the time for lease rental payments due Alaska.

Drilling News - Standard-Richfiela completed SCU 41-4 (see above) and 1s now rigging to drill SCU 32-4, also flshing in SRU 14-27 and drilling below 5200 in SRU 32-10. Ichfleld drlliting below 12,700 in Kallakh No. 1 near Yakataga. No recent news from Jenedum and Associates at the Nulato Unit No. 1.

\section{STATE LFGISLATIVE NEWS}

The Legislature has just adjourned, and we present here the status of the bills and new laws of interest to the minerals industry as well as we know it at the time of writing.

None of the varlous bills for establishing boroughs passed.

AB 264 for a revolving mine loen fund ded in committee.

BB 333 to cancel the uranium bonus offer passed and was signed by the Governor Into 18 w.

HB 339 to allow for geophysicel, geochemical, and geological assessment work passed and was signed by the Governor. Detalls on this Act will be given elsewhere in this Bulletin. 

HB 341 to take the DIvision of Econamic and Tourist from the Department of atural ReBources and place it under the Department of Comerce passed and w1Il probsbly e slgned.

EB 366 to authortze the construction or repair of pioneer access roeds into and within areas rich in natural resources (not just minerals) passed and has been supported by an eppropriation of $\$ 1,000,000$. The money wlll not be avallable before July 1 . More detalls on this Act next month.

SB 150 to change the annual assessment work date from July 1 to September 1 pased and has been slgned into law.

SB 153 to change the filing and holding requirements of confidential oil weli Information pessed and has been signed. Details are elsewhere in this Bulletin.

SB 190 to change the examination and certiflcation of construction industry explosives handlers from the Division of Mines and Minerals to the Department of Iebor has been signed by the Governor.

SB 222 to authorize the Department of Natural Resources to make regulations in the flelds of safety in all mining operations and minerel conservation in coel mining operations passed and undoubtedly will be slgned into law.

SB 249 to restrict the crossing of strean beds whth equipment at other than regular crossiogs without first notifying the Comissioner of Fish and Geme was passed and will probally be signed. This bill is an addition to the Fish and Geme Code (Chapt. 94 SLA 1959) where, as explained last yoar, miners and others using streams must report what they lntend to do, and the Comissioner of Fioh and Game may then make certain requirements if he feels it is necessary to protect the fish. The pertinent pert of this Act will now read as follows, whth the newly-added wording underlined:

"Sec. 31. PROTECTION OF FISH AND GAME. In the event that any person or goveramental agency desires to construct any form of bydraulic project or to use any equipment that wlll uBe, divert, obstruct, pollute or change the natural flow or bed of any river, lake or stream or to use, except for the purpose of croseing a river or stream it an established crossing, any wheeled, tracked or excavating equipanent or log dragging equipment in the bed of any river, lake or stream containing anadromous fiah or that will ut1lize any of the waters of the State or materlals from any river, lake or stream beds, such person or governmental agency shall notify the Commissioner of such 1utention prior to the commencement of conatruction, and the Comissioner shall ackowledge receipt of such notice by return ma1l. If the Commissioner so determines, he shall, in seid letter of ackowledgement, require auch person or governmental agency or submit to him full plans and specifications of the proposed construction or work, complete plans and spec1fications for the proper protection of fish and game in connection therewth, and the epproxdmate date when such construction or work ls to conmence, and shall require such person or govermmental agency to obtain the written approval of the Commiasioner as to the sufficlency of such plans or specifications before construction is commenced. . .."

\section{HEARING ON OII REGULATIONS}

As a result of the emendment by SB 153 to the 011 and Gas Conservation Act, Chepter 40, SIA 1955, relating to the flling and holding of well informetion, a hearing 


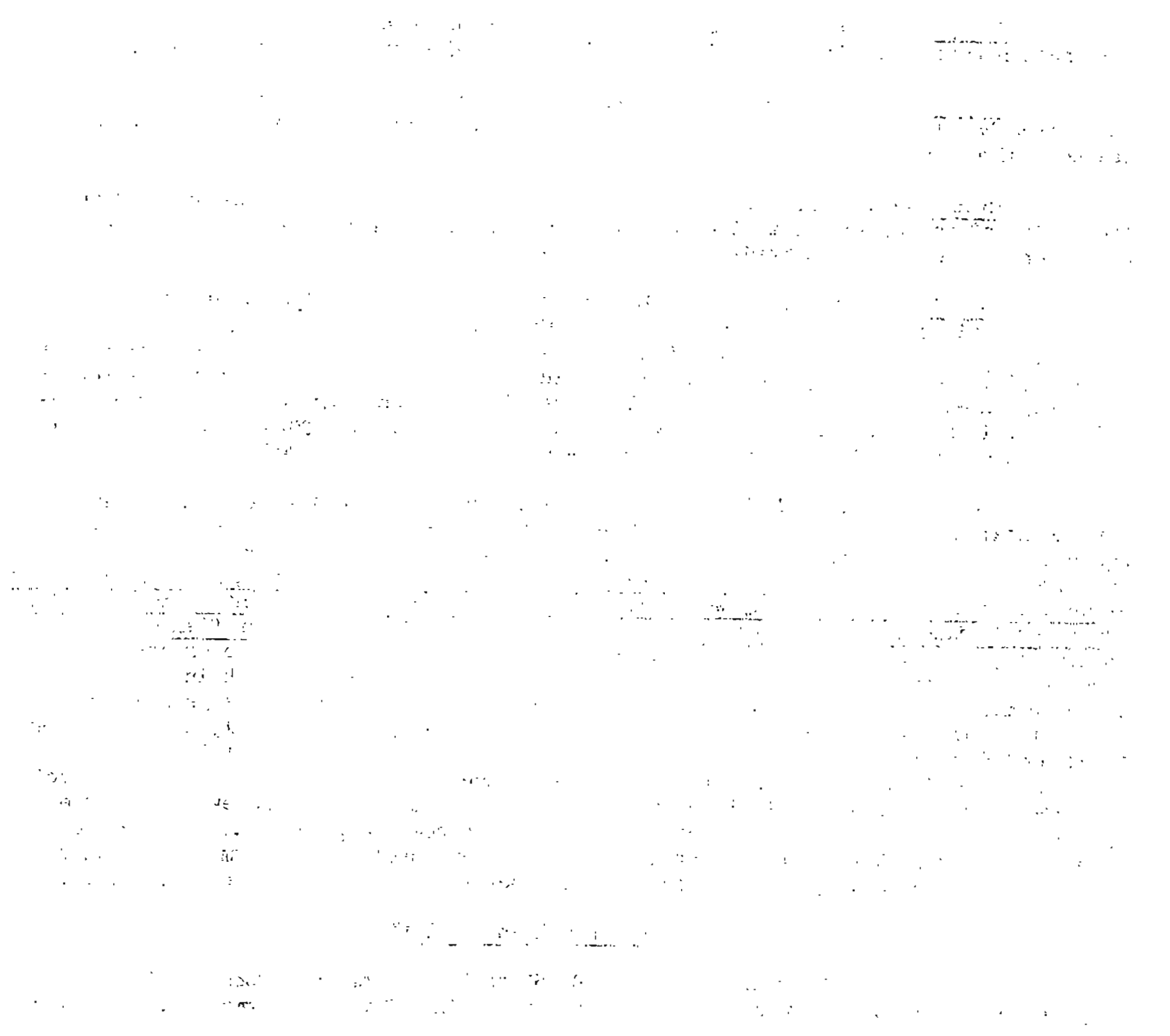


Is now necessary to amend the pertinent regulation to agree with the Act. This opportunity will also be used to make other regulation changes which have been found to be advisable

ith the increase of petroleum activity since the existing regulations were adopted on Aug. 7, 1958. The hearing will be held in May. Thirty days' advance notice will be published. The proposed changes are not quite ready, but they will be malled shortly to our oil and gas industry mailing list from this office. Others may receive them by writing to this ofize or contacting our Anchorage office.

The amendment to Subsection $4(a)(2)$ of section 4 of Chapter 40 now allows the Division of Mines and Minerais to require:

"(2) The making and filing of reports, well logs, drilling logs, electric logs, Ifthologic logs, directional surveys, and all other subsurface information on any well drilled for oil or gas, or for the discovery of ofl or gas, or for geologic informetion; provided, however, that the required reports and information shall be filed within thirty (30) days after the conpletion, abandonment, or suspension of the well; provided further, that required reports end information marked 'confidential' shall be kept confidential for twenty four (24) months after the 30-day piling period, unless the owner gives

ritten permiosion to release such reports, logs, or other information at an earlier date."

ANNOUNCEMETT TO THE COAL INDUSTRY

The State Division of Lands at 333 D Street, Anchorage published the following letter to the coal industry on March 16:

"To Members of the Cosi Indugtry:

"This letter is being sent to you in response to your request that your name be placed on the maling list to recelve important announcements with regard to coal activity in Alaska.

"Enclosed you will ind a copy of the Alaska State Coal Regulations which will becone effective April 15, 1960.

"No lands will be made available for flling until classlication of the area has been determined, proper notice given, and the regulations becore effective."

Section 522.1] of the new regulations states: "Any citizen of the United States over 21 years of age may request that any lands be classifled as cosl lands. . . . If a request for classification as coal lands is denied, the requestor will be given an exclusive right for a thirty day period to apply for a prospecting permit under section 525. of these regulations." Leases may be obtained on classified coal lands by competftive bldding only, but a prospecting permit can be converted to a noncompetitive lese upon production or upon a showing of workable coal deposits. All the above pertaing only to State-owned lands, of course.

\section{NEW ASSESSMENTI WORK PROVISIONS}

Chapter 26, SLA 1960, is the new assessment work date law. It sete forth that the assesment work year now begins at noon on the first day of september each year.

The passing of 1 B 339 allowg for geological, geochemicel, and geophysical work to count as annual assesiment work by ading two new sections to our state mining law as follows: 
. i .

. 
"Séc, 47-3-61. SURVEYS INCLUDED AS ANNUAT LABOR. The term 'labor' where used in Sections 47-3-51, 47-3-52, and 47-3-9.1, ACLA 1949 shall include, without being limited so, geological, geochemlcal and geophysical surveys conducted by qualified experts and verifled by a detailed report filed in the recording precinct office in which the claim is located which sets forth fully (a) the location of the work performed in relation to the point of discovery and boundaries of the claim, (b) the nature, extent, and cost

thereof, (c) the basic findings therefrom, and (d) the name, address, and professional beckground of the person or persons conducting the work. Such surveys, however, may not be applied as labor for more than two consecutive years or for more than a total of f1ve years on any one mining claim, and each such survey siball be non-repetitive of any previous survey on the same claim.

"Sec. 47-3-62. DEFINITIONS. As used in sec. 47-3-61:

"(a) The term 'geological surveys' means surveys on the ground for mineral deposits by the proper application of the principles and techniques of the science of geology as they relate to the search for and discovery of mineral deposits;

"(b) The term 'geochemical surveys' mean's' surveys on the ground for mineral deposits by the proper application of the principles and techniques of the science of chemistry as they relate to the search for and discovery of mineral deposits;

"(c) The term. 'geophysical surveys' means surveys on the ground for mineral deposits through the employment of generally recognized equipment and thods for messuring physical differences between rock types or discontinulties in geological formations;

"(d) The term "qualifled expert" means an Individual qualified by education or experience to conduct geological, geochemical or geophysical surveys, as the case may be."

\section{CONGRFSSIONAL NEWS}

S: 2033 passed both Houses and was awaiting the President's slgnature at last report on March 10. This bill would amend the mining laws to permit 5-acre millsites on nomineral ground to be patented simutaneously with plecer claims, where millsites are needed in connection with mining the claims.

S. 1123 for a National Wilderness Preservation system is still belng carrled along with occasional hearings. This bill would establish an extensive National Wilderness Preservation System composed of Federally owned or controlled land and water areas within which virtually all comercial enterprise would be banned. Huge arees in Aleska would be 1ncluded. An attack against the bill was led by Senator O'Mahoney (Dem., Wyo.) who sald the measure should be entitled "A bill to relieve Congress and Its Members of their responsibilities under the Constitution" instead of a bill to create a wilderness system. He and otber western senators favored amendments which would require the approval of Congress before wilderness areas could be created.

\section{ETCETERA}

Aluminum w1ll now be used in high-tension transmission towers. The towers are of a guyed design and will be all-aluminum. The 96 -foot high 345 kllovolt tower will contain ebout 2,700 pounds of aluminum against 7,500 lbs. Of steel for a similar structure. 
E\&MJ says that nickel cadmium batteries may bring back the electric car. Sonotone Corp. and American Motors heve announced a joint research program to study the possibilities.

The AEC has approved the export to Rusis of a gmall quantity of radioective byproduct material for sclentiflc, nonmlitary use. The material is 5 microcuries of carbon 14 and is to be used in medical study by the Academy of Medical Sclences at Moscow.

A hearing w113 be beld in Oregon over the request for a patent on 17 mining claims in the Unpqua. National Forest. The clatus have produced $\$ 400,000$ over the past 50 yeara, but are presently iale. Timber on the clajms is valued at $\$ 24,400$. The purpose of the hearing is to place on record any protests against granting the patent.

The State Division of Lands, 333 D Street, Anchorage, w1ll hold hearings on proposed regulations for disposal of timber and materials (grivel, etc.) on State-owned lands durlng Kay. Firther information may be obtained from the Division of Lands.

E. AND M. J. METAL MARKET PRICES

\begin{tabular}{|c|c|c|c|}
\hline & $\begin{array}{l}\text { MAR. } 24 \\
1960\end{array}$ & $\begin{array}{l}\text { Month } \\
\text { Ago } \\
\end{array}$ & $\begin{array}{l}\text { Year } \\
\text { Ago }\end{array}$ \\
\hline $\begin{array}{l}\text { Copper, per lb. } \\
\text { Iead, per lb. } \\
\text { Zinc, per lb. } \\
\text { Tin, per lb. } \\
\text { Nickel, per lb. } \\
\text { Platinum, per oz. } \\
\text { Qulcksilver, per flask } \\
\text { Silver, forelgn, New York } \\
\text { Silver, domestlc, per oz. } \\
\text { Antimony ore, per unit } \\
\text { Curome ore, per long ton } \\
\text { Molybdenum conc., per lb. } \\
\text { Titanium ore, per ton } \\
\text { Tungsten ore, per unit }\end{array}$ & $\begin{array}{l}33.04 \\
12 \phi \\
134 \\
99.84 \\
74 \phi \\
\$ 81-85 \\
\$ 274-216 \\
91.44 \\
90.54 \\
\$ 3.30-3.35 \\
\$ 35-36 \\
\$ 1.25 \\
\$ 23-26 \\
\$ 22-24\end{array}$ & $\begin{array}{l}33.1 \phi \\
12 \phi \\
13 \phi \\
100.2 \phi \\
74.4 \\
\$ 82-85 \\
\$ 213-216 \\
91.4 \phi \\
90.54 \\
\$ 3.30-3.35 \\
\$ 34-35 \\
\$ 1.25 \\
\$ 23-26 \\
\$ 22-24\end{array}$ & $\begin{array}{l}32.04 \\
11.54 \\
11 . \\
102.54 \\
744 \\
\$ 75-80 \\
\$ 227-230 \\
91.44 \\
90.54 \\
\$ 3.10-3.20 \\
\$ 40-42 \\
\$ 1.25 \\
\$ 23-26 \\
\$ 19-22\end{array}$ \\
\hline
\end{tabular}

